\title{
Turning the Tide
}

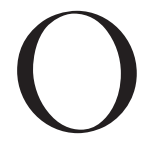

N NOVEMBER 1944, the American master dam builder John Lucian Savage produced the blueprint for a massive hydropower station that straddled the Yangtze River. Standing 738 feet, the proposed dam would have been twelve feet taller than the Grand Coulee, which was then the highest dam in the world, but the electricity produced by its ninety-six mighty generators would be five times that of its American counterpart. ${ }^{1}$ For the first stage of its development, Savage ordered "the excavation and concrete lining of all (twenty-six) tunnel and shaft systems" that could be either concentrated on one side of the river or divided between two sides as depicted in figure 5.I. He also called for the construction of earth and rock fill cofferdams, the completion of six tunnel systems for four main and two station service systems, and the installation of sixteen main power units. ${ }^{2}$ Jack Savage, the "Billion Dollar Beaver" even quipped that the Yangtze Dam would make the Boulder Dam, which only had four diversion tunnels, "look like mud pie." 3 Savage, however, did not specify the amount of time needed to complete the project. The construction would presumably be quick; returns on investment would also be high. He projected that twenty years of electrical power revenue would easily cover the 653 million US dollars needed for stage one. To him, all that mattered was that the Yangtze Gorges Dam would be a "CLASSIC" that would "change China from a weak to a strong nation." ${ }^{\text {"’ }}$

Savage did not conjure the dreams of accelerated development on his own. The vital spark of imagination came from two young Chinese engineer-bureaucrats trained at the Tennessee Valley Authority (TVA) during the height of World War II. Sun Yun-suan, the future premier of Taiwan, and Zhang Guangdou, the future vice-chancellor of Tsinghua University in Beijing and advocate for the Three Gorges Dam, were among thirty-five engineers dispatched to the United States for this advanced training. They survived an arduous 15,504-mile journey across four continents. On their way to the United States, both men fell ill with malaria as they moved through sub-Saharan Africa and received treatment at a US Army Hospital in Accra, Ghana. The TVA, where they spent the 


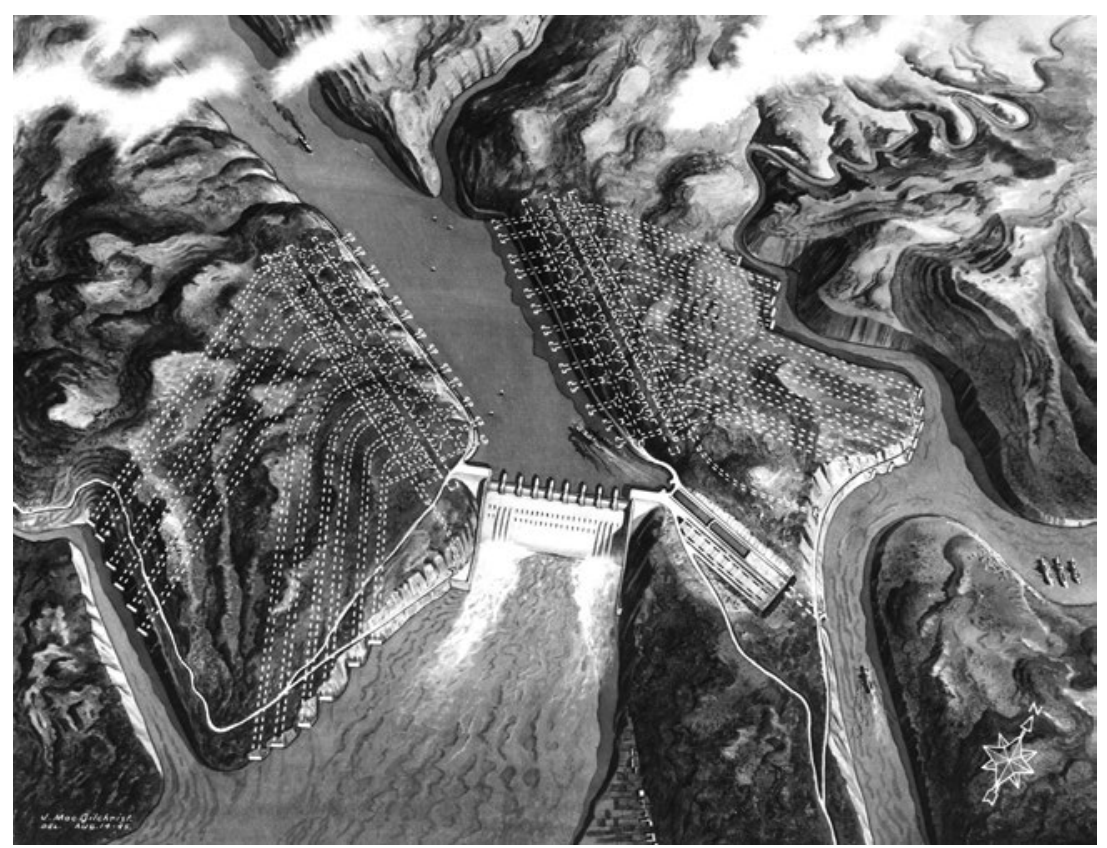

FIGURE 5.I. Artist Impression of John Lucian Savage's Proposed Yangtze Gorges Dam at Yichang. Source: John Lucian Savage Papers, box 4, American Heritage Center, University of Wyoming.

most formative years of their training, happened to list malaria eradication as one of its objectives. ${ }^{6}$ Inspired by the federal government's achievements, Zhang and Sun introduced themselves to Savage and described China's vast potential for hydropower development to the American dam builder.

Chinese engineer-bureaucrats selectively appropriated parts of the TVA's management practices that would allow China's state agencies to strengthen their grip on the electrical power sector. Unlike David Ekbladh and Christopher Sneddon, whose work primarily discussed how the TVA served American national interests, this chapter focuses on how the Chinese adapted lessons learned from the Americans to address pressing needs of national reconstruction. The TVA's technical assistance, which in the words of Sneddon, worked as "a geopolitical tool within the apparatuses of the American state as it sought to extend its influence over the underdeveloped regions of the planet in the mid-twentieth century." No doubt, the Americans won over the hearts and minds of the Chinese trainees by graciously welcoming them to work alongside them at TVA sites. The Chinese engineers showed less interest in the "public-private cooperation," 
which, according to Ekbladh, set the TVA apart from statist Nazi Germany, the Soviet Union, and imperial Japan. ${ }^{8}$ Having spent their early careers forcing private operators to comply with state regulations with limited success, the Chinese trainees looked toward the TVA for a roadmap to accelerated economic development under the auspices of centralized state power.

The hubris of victory gave rise to a blank-slate mentality that took hold among the Chinese engineers and their American counterparts. Sheltered from the vagaries of war on the American home front, Chinese engineers like Zhang and Sun observed how an American federal government agency worked without interference from private enterprise to raise the living standards of its citizens in the rural South through integrative river basin developments. The Allied Victory strengthened their conviction about the viability of the TVA model in China. Their plans for accelerated development of hydropower came at a time, when the tide of World War II was turning in the favor of the Allied powers. Savage's Yangtze Gorges proposal exemplified this blank-slate approach. Their grandiose plans failed to consider basic factors such as geology, sedimentation, and, most important, budgetary constraints of a postwar state. The time and energy spent on the megadam project diverted valuable resources from smaller hydropower projects that could have been completed in a shorter timeframe and addressed power shortages. The defeat of the Guomindang regime in the Chinese Civil War (1946-1949) would dash the dreams of accelerated development.

\section{Forging Sino-American Technological Diplomacy}

The TVA, an agency established under Roosevelt's New Deal, provided an ideal training ground for China's engineer-bureaucrats. Its projects exemplified the centralized approach to infrastructure and industrial development that the NRC sought to emulate. While NRC's engineer-bureaucrats had considerable experience in salvaging electrical power systems, they lacked expertise in designing large-scale hydropower plants and managing long-distance transmission networks. Their training at the TVA led to a shift in their mindset from survival mode to long-term strategic thinking. The integrative river basin developments, which achieved multiple objectives of flood control, fertilizer production, land reclamation, and hydropower generation and distribution, inspired the Chinese engineers to outline ambitious plans for national reconstruction. The engineer-bureaucrats even visualized TVA project sites in Tennessee, Alabama, and Georgia as microcosms for large-scale power developments undertaken at the national level that would catapult China into the ranks of industrialized nations. 
The TVA and China's Nationalist government learned that they shared a common vision of the government's role in industrial development, paving the way for the TVA's partnership with the NRC. The New Deal's opponents accused President Franklin Delano Roosevelt of using federally funded projects to secure absolute political power. Lilienthal learned about a speech that $\mathrm{Hu}$ Shi, then China's ambassador to the United States, delivered at the bicentennial conference of the University of Pennsylvania on September 19, 1940. Hu argued that there is no "danger of dictatorship" in the United States, citing the fact that the president "cannot carry his own Dutchess County during all the eight years of his administration," and "when the party in power controlled 80 per cent of the votes in both Houses of Congress, the President could not push through Congress some of the legislation which Congress did not like." David Lilienthal, co-director and later first chairman of TVA, expressed his gratitude to $\mathrm{Hu}$ for his spirited defense of the federal government and offered to call on the ambassador at Washington, DC. ${ }^{10}$ Before departing from his post in $1942, \mathrm{Hu}$ spoke in Nashville but did not stop in Knoxville to bid farewell to Lilienthal. A year later, the Cornell-trained electrical engineer Huang Hui, who was visiting the TVA, presented Lilienthal with a fan with a picture of the goldfish on one side and an inscription written by Hu Shi on the other. Hu's chosen passage was from military strategist Sun Zi's essay "On Nature," which aptly summed up the objective of the technological diplomacy between the NRC and TVA: "If you let things multiply by themselves, will it not be better to apply your effort to transform them?"11

Back in Chongqing, the NRC began nominating candidates for advanced training in the United States. With electricity emerging as the main focus of applied science research during the war, more than one third of those selected (twelve out of thirty-five) came from the power generation and electrical equipment industries. The NRC carefully rationed limited training opportunities among its industries. The electrical equipment industry was limited to six nominees. Yun Zhen had already secured internships for Chu Yinghuang and Lin Jin to study power generators at Westinghouse. He assigned the four remaining slots to high priority areas and made a compelling case for each of his nominees. In his recommendation for Tang Mingqi, a twenty-nine-year-old deputy engineer with the Central Electrical Works who had worked at Shanghai Siemens and the Chinese-owned Huacheng Electrical Plant before joining the Electrical Works as a circuit designer, Yun drove home the point that transformers served as "the lifeline of electrical systems, and the quality of design and production quantity will determine the fate of our electrical power sector." ${ }^{12}$ Besides 
vouching for Tang's work ethic, Yun stressed the importance of learning new production methods to overcome existing limitations. He acknowledged that the Electrical Works was capable of producing medium and small transformers on an ad-hoc basis, but "encounter[ed] considerable difficulty in manufacturing high-voltage and large transformers and the mass production of medium and small ones." 13

Engineers outside the power generating and electrical equipment industries highlighted the connections between their areas of expertise and electricity. Wu Daogen, a specialist in alloy manufacturing, provides the most telling example. Wu listed eight different types of steel smelted in electrical furnaces in his essay before declaring that, "the furnace is at the heart of alloy manufacturing, so it is necessary to pay attention to the supply of electrical current, the circuitry, electro-thermal efficiency" among other things. He pointed out that the electrode was the heart of the furnace, as "it facilitates the transformation of electrical energy to heat, which allows the melting of metals and creation of alloys." ${ }^{14}$ No amount of manual labor can transform iron ore into electrical steel. It was electricity that enabled vital chemical reactions in materials processing.

Successful candidates had distinguished themselves in the line of duty. Sun Yun-suan and Zhang Guangdou salvaged power generating equipment to build electrical power systems from the ground up with little logistical support in far-flung regions. Zhang, who had graduated from the University of California at Berkeley and Harvard University, rushed back to China when the second Sino-Japanese War broke out in 1937. The NRC ordered him to rehabilitate the Longxihe hydropower station, sixty miles northeast of the wartime capital Chongqing - the process of which was discussed in the previous chapter. Sun, who had studied with Soviet instructors at Harbin Engineering University and joined the NRC in 1936 after working as an engineer at the Lianyungang Power Station in Jiangsu, quickly earned Yun Zhen's trust. As seen in the opening paragraphs of chapter 3 , Sun coordinated the evacuation of power generation equipment from Lianyungang to Ziliujing in Sichuan. Sun was later deployed to Xining in the sparsely populated Qinghai Province to build a coal-fired power station. As the electrification of Xining failed to stimulate the development of industry, the NRC's director, Weng Wenhao, transferred Sun to Tianshui in Gansu Province. ${ }^{15}$

Sun and Zhang delayed their departure for the United States for several months. Their colleagues began leaving in Chongqing and Kunming in batches in June $1942 .{ }^{16}$ With the Pacific Ocean closed to civilian air traffic after the bombing of Pearl Harbor, the Chinese engineers flew across the Himalayan 
Hump from Kunming to Calcutta and waited for weeks before they could board the short flying boats of the British Overseas Airways Corporation, which hopped from city to city along the Indian coastline, Arabian Gulf, and Tigris River until they reached Cairo. They headed into sub-Saharan Africa on US Army Air Transport, before flying to Belem in Brazil, where they boarded a ship to take them to Miami. ${ }^{17}$ A typical journey involved 15,506 miles of flights with twenty-eight transfers. Air sickness, harsh weather, endless waits, and sleep deprivation were part and parcel of this tortuous trip. With no delays, the journey from China to the United States took about five weeks. ${ }^{18}$ That was rarely the case.

Following the same travel itinerary as their colleagues who traveled before them, Sun and Zhang encountered numerous obstructions along the way. But they found meaning in the sights and sounds of their arduous journey. One of Sun's most memorable moments was the flight on a BOAC flying boat over the Suez Canal on the tenth leg of his journey. ${ }^{19}$ It conjured his memories of toiling in the arid regions in Northwest China. Sun wrote in his diary on March 27, 1943:

In this boundless sandy desert, where one can barely see people walking around, there are roads filled with vehicles and oil pipelines that run for hundreds of miles. Hundreds of fearless engineers toiled tirelessly and selflessly, in order to make such a contribution to mankind. The crisis of our nation is deepening. We should be ashamed to death that so many of our young and accomplished engineers shake their heads incessantly at every mention of Northwest China. ${ }^{20}$

The sight of the canal and pipelines in the desert brought to mind the NRC's Yumen Oil Fields in the deserts of northwestern Gansu. As the superintendent of Tianshui Power Plant hundreds of miles east of Yumen, Sun knew too well the unwillingness of young engineers to take up hardship postings in Northwest China.

Sun and Zhang also fell ill with malaria, further delaying their journey. They ran straight into the North African campaign and could not fly farther west from Egypt, so they headed south toward modern-day Sudan, Chad, Nigeria, and Liberia on US Army Air Transport. The US Army transport planes ferrying Sun and Zhang could have played a part in speeding up the spread of malaria. ${ }^{21}$ On April 18, 1943, while in Accra, Ghana, Zhang awoke to paroxysms of high temperature, chills, and profuse sweating. Five days later, Sun exhibited the same symptoms. Sun filled a gaping hole in his dairy between April 26 and May 3, 1943, with a phrase "Receiving treatment for malaria at a US military hospital 
at Accra." 22 They recovered by May I2, just in time for the next flight out from Accra to Natal in Brazil. On May 20, 1943, Zhang Guangdou established contact with the New York office of the NRC for the first time in the ten-week journey, informing the director, Chen Liangfu, that he and Sun Yun-suan would depart from Miami by train to Washington, DC. ${ }^{23}$ Sun and Zhang stopped by the Library of Congress to gather research materials before reporting to the New York office on May 27.24

Convinced of the comprehensiveness of TVA's training program, Sun and Zhang abandoned their original plans and headed out to Knoxville, Tennessee. Sun had applied for a twenty-one month posting to the transmission and relay department at Westinghouse or GE to learn more about long-distance power transmission; Zhang Guangdou, who had supervised the Wanxian hydropower project, was planning to study dam building at the Bureau of Reclamation. ${ }^{25}$ Chen Liangfu persuaded them to take on a broader training program at the TVA. Both arrived together at Knoxville, Tennessee, on June 23, 1943. Zhang also became the only trainee for dam building in his cohort, as his fellow hydroelectric engineer Jiang Guiyuan was confined in a sanatorium after being diagnosed with tuberculosis upon his arrival in the United States.

The TVA not only provided hands-on experience in project management to the Chinese trainees but also hosted activities to rally support for China's war effort. Seven out of the thirty-five engineers received advanced training at TVA facilities. Other trainees attended regional conferences held at TVA project sites. The Chinese engineers exhibited their professionalism by attending these events dressed neatly in suit and tie. They also expressed their appreciation for American assistance by delivering carefully scripted statements to the press. The dates of the conferences also coincided with important anniversaries. The second local meeting between May I5 and I8, 1943, at Wilson Dam in Florence, Alabama, was held in conjunction with the tenth anniversary of the TVA. The third regional conference at Chattanooga on August 13, 1943, was scheduled on the same day as the sixth anniversary of the battle for Shanghai. ${ }^{26}$ The TVA Engineers Association put up a statement of support for their Chinese counterparts and used these occasions to reaffirm Sino-American friendship.

Diplomatic pleasantries aside, Chinese trainees at the TVA kept themselves busy with a packed training schedule. Zhang, whose training laid the groundwork for a career in dam construction, offered a glowing assessment of the TVA in his first training report submitted to the NRC's New York office, listing "the rapid progress of hydroelectric development with up-to-date construction methods and practices, the unified plan of the development, the close resemblance of 
our Commission and the Authority in ideas" as key advantages. ${ }^{27}$ Zhang started by working on designs and drafts. In his August 1943 report, Zhang, however, complained that this training method was "quite inefficient. Because every single drawing takes about one month, and most of the time is used in making fine drawings according to standards." ${ }^{28}$ Zhang's supervisors approved his transfer to a higher level, where he studied design features and key structural elements of hydroelectric projects. Zhang obtained firsthand experience on the division of labor and specialization required for the planning and building a hydroelectric plant.

Sun, alternately, gained expertise in power generation and transmission. He did not stray from his objective of "paying close attention to the flexible application of power grid designs, hereby ensuring the stability of transmission voltage and frequency" spelled out in his application. ${ }^{29}$ He learned about cost-effective power grids, emergency electrical power deployment systems, lightning protection mechanisms, and interconnected regional power systems. Every segment of his training covered a lot of ground. His time at the power operation department was divided into six sections. He started out with the system operations division for eleven weeks, where he learned power statistics, load dispatching, substation operation, and relay and protection. He spent six weeks covering hydroelectric and thermal power production, then moved on to electrical testing, power system servicing, substation maintenance, and transmission line maintenance for one week each. ${ }^{30}$

Besides summarizing key lessons, training reports also contained vital intelligence that helped the Chinese government negotiate favorable terms for technical assistance. Within the first month at the TVA, Sun and Zhang learned about Soviet-US cooperation in hydroelectric projects. On July I8, 1943, Zhang Guangdou sent a memorandum to Chen Liangfu informing him that five Soviet engineers arrived in Knoxville to seek TVA's assistance with hydroelectric dams under the Lend-Lease Agreement. ${ }^{31}$ Sun, who had studied under Soviet instructors at Harbin Engineering University, spoke with the Russians. ${ }^{32}$ He even helped design eleven of the eighteen small-scale hydroelectric plants for the Soviets during his first month of training in the TVA's design department. ${ }^{33}$ In his first training report sent to the New York office, Sun expressed his amazement with these stations that were "Equiped [sic] with supervisory control and telemetering equipment, which means that stations can automactically controled [sic] from the center control station." ${ }^{34}$ These small hydroelectric stations had a power output of less than $5,000 \mathrm{~kW}$ and directly connected to high-voltage transmission lines that delivered electricity over longer distances. This resembled 
the NRC's plan for Sichuan. Zhang thus urged the Resources Commission to request technical assistance on terms similar to the Soviets. Chen Liangfu wrote to Lilienthal after receiving reports from Sun and Zhang but was told to seek authorization from the State Department, Lend-Lease Administration, or the Office of Foreign Economic Administration. ${ }^{35}$

The trainees also saw the TVA as a model for techno-nationalist development. In his August 1943 report, Zhang expressed amazement with the TVA's "unified plan of development ... to reach the most economical and maximum benefit as a whole." ${ }^{36}$ Zhang acknowledged that building power systems solely with government resources can be cumbersome but believed that the benefits outweighed the costs. ${ }^{37} \mathrm{He}$ recognized that private firms may be more efficient in catering to market demand, as they could carefully evaluate "cost, desirability, necessity, or soundness prior to adoption and authorization." 38 That said, the nine advantages of public developments outweighed the benefits from market efficiencies. The government incurred lower interest rates, improved social welfare by bringing electrical power to underdeveloped regions, and considered other long-term benefits such as national defense and improvements in overall living standards. Zhang concluded, "After a decade of controversy, the trend of power utilities proceeds in the direction of public control, although very slowly. The progressive minds believe that for the public weal [sic] the power utilities should be developed and regulated by the government." ${ }^{39}$ Zhang's observations of the TVA provided talking points for the NRC to present a compelling case that a state monopoly over the electrical utilities would yield the greatest good to the greatest number of people.

Zhang saw abuses by private contractors as the main source of wastage in US government projects. After transferring to the Bureau of Reclamation in 1944, he compared the operations of the TVA with those of the Bureau of Reclamation. He observed that the TVA tended to complete projects on its own, while the bureau mostly hired private contractors. He conceded that contractors achieved cost savings by using the same set of equipment for multiple projects and quickly adjusted labor inputs to meet project deadlines. Zhang, however, argued that the disadvantages outweighed the benefits. At the Bureau of Reclamation, Zhang noticed that contractors reaped excessive profits by sacrificing work quality to save on labor and materials. He thus concluded that the TVA's exclusion of contractors allowed it to maintain greater quality control. Granted that there was too much red tape and substantial waste of material and labor, Zhang asserted that most TVA employees "believe that these wastes will be greatly outbalanced by the low quality and over-profit of a contractor system." ${ }^{\text {*0 }}$ Taking over as chief 


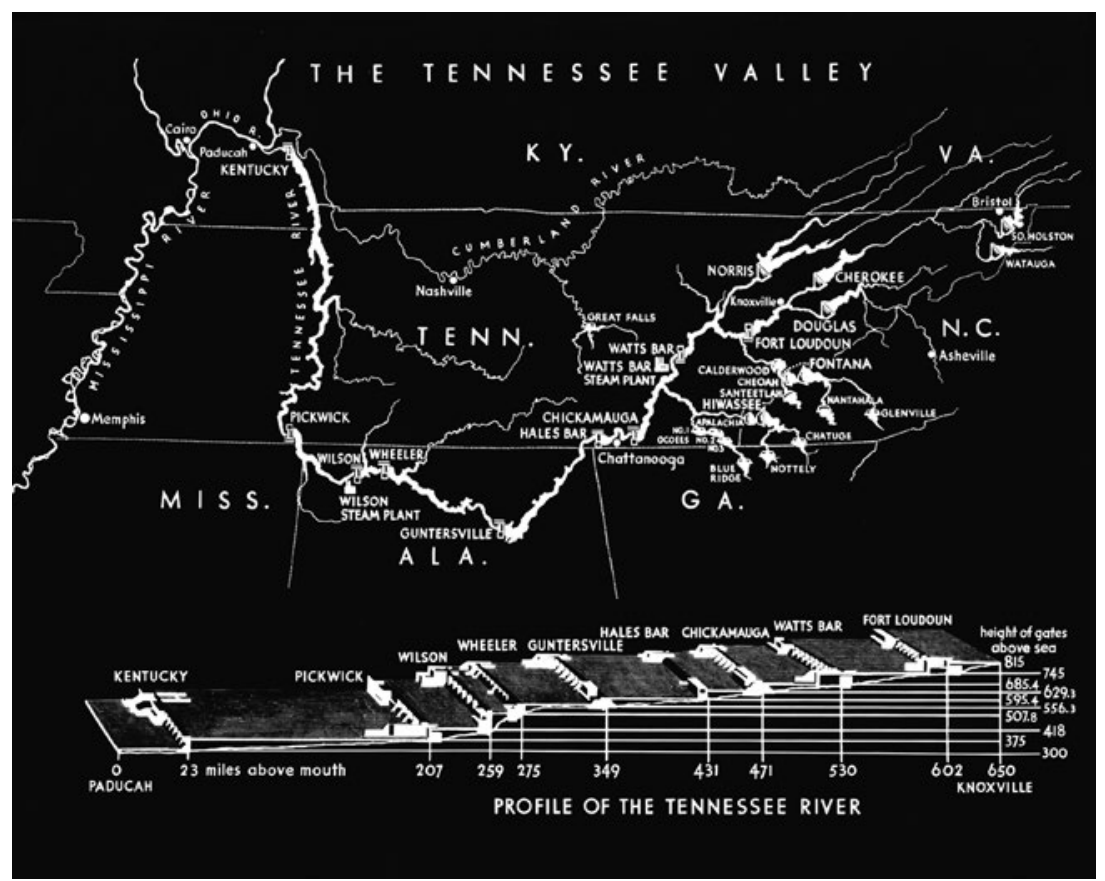

FIGURE 5.2. Profile of the Tennessee River (1944). This map appears in

Sun Yun-suan's report to the NRC office in New York. The integrative development of the Yangtze River is a scaled-up version of the Tennessee River hydropower projects. Source: RG82: Tennessee Department of Conservation

Photographs, box 69, courtesy of Tennessee State Library and Archives.

engineer of the National Hydroelectric Commission in 1946, Zhang modeled its workflow after the TVA by centralizing aspects of planning for hydroelectric projects. Zhang found this arrangement optimal, as he believed contractors in China were ill-equipped to construct massive dams.

The TVA's power network inspired the Chinese trainees to imagine a future when surplus power could be seamlessly transferred across the nation. In his February 1944 report, Sun expressed his fascination with how the TVA maintained a consistent load of $700,000 \mathrm{~kW}$ year round by transferring surplus power with a $154 \mathrm{kV}$ high-voltage transmission line between its western and eastern regions, which were 125 miles apart, as shown in the map in figure 5.2:

In the spring, rainfall is more abundant, and the hydro-electric plants downstream in the western region are able to provide more electrical 
power. During this time, the hydroelectric plants upstream on the eastern tributaries begin to store water and generate less electricity, in order to prepare for the dry seasons. During this time, the western regions will transfer its surplus energy to the east. ${ }^{41}$

The process was reversed during the dry season in the fall. The Yangtze Gorges project, which will be discussed in the second half of this chapter, could be thought of as a scaled-up version of the power network in Tennessee described by Sun. Attempts to scale up the TVA's projects on a national level proved to be unfeasible, as existing technology made it unrealistic to build transmission cables that would carry high-voltage current seven hundred miles from the upstream areas to the industrial centers in the Lower Yangtze.

The TVA's cost-competitiveness also caught the attention of the NRC's senior officials. Liu Jinyu, who had built Kunming's wartime power stations, visited the power office in Chattanooga. He described the private operator ConEdison's performance as "rather mediocre," and its electric tariff of 2.4I cents per kWh as "rather high in this country," after learning that the TVA charged a fraction of its cost. ${ }^{42}$ Most important, Liu concluded, citing TVA's power policy, "the interest of [the] public in the widest possible use of power is superior to any private power interest. ${ }^{\prime 33}$

Yun Zhen, who had fended off Westinghouse's attempt to impose American voltage standards on China, shared Liu's sentiments. Yun led a delegation to the Tennessee Valley between December 3 and 13, 1944, which visited several major dams and heavy industries powered by abundant electricity. His distrust of private enterprise further deepened during this trip. While all other heavy industries in the Tennessee Valley welcomed the NRC, the Aluminum Company of America (Alcoa) declined to host the Chinese delegation. ${ }^{44}$ The TVA office warmly welcomed Yun and his colleagues. Its chief engineering office presented the delegates with a detailed profile and map of the Tennessee River System that had appeared in Sun's earlier report (figure 5.2). ${ }^{45}$ Yun later drew on his field notes from the visit and trainee reports to strengthen his case for the nationalization of the power sector. Yun Zhen's note of appreciation to Lilienthal stood in stark contrast to his short but cordial thank-you notes sent to private corporations that hosted their visit. After returning to New York, Yun told Lilienthal:

The services that the Authority rendered, and is rendering, in the interest of the people give us immeasurable encouragement as to how well government-operated enterprise could attend to the betterment of people's 
livelihood. As men devoted to the development of national resources in China, we find TVA a source of inspiration and, no less, a big challenge. ${ }^{46}$

The NRC eventually realized the immensity of the challenge when they attempted to apply the lessons learned at the TVA in China with the planning and design of the Yangtze Gorge project between 1944 and 1947.

\section{Replicating the TVA in China}

Personal contact between TVA trainees and American dam builders paved the way for Sino-American cooperation in integrative river-basin development. A letter from Zhang Guangdou in September 1943 stoked the imagination of John Lucian Savage, the chief designing engineer for the Bureau of Reclamation. Zhang introduced himself to Savage before his transfer from Knoxville to Denver. His letter came months before the State Department memo to Savage telling him that his work is "expected to be useful to the war effort. ${ }^{3{ }^{37}}$ Zhang saw in Savage, to quote Sneddon, "key traits of the idealized technical expert: virtuosity in terms of technical knowledge, a capacity to innovate, and an almost metaphysical understanding of how technology might be best applied to promote human welfare. ${ }^{378}$ Zhang presented China as a land of opportunity for massive integrative river basin developments by attaching a report of China's postwar electrification plan, which included "I 4 major hydro-electric power plants in all with an aggregate generating capacity of $400,000 \mathrm{~kW}$, to be constructed within five years after the conclusion of the war. ${ }^{349}$

Zhang explicitly made the connection between industrialization and hydropower development on top of providing a snapshot of the hydrological surveys conducted in Sichuan, Yunnan, Guizhou, and Hunan since the Nationalist retreat to Southwest China. The $40,000 \mathrm{~kW}$ Zi River hydropower station, for example, would be built near the antimony production center of Xinhua, whereas the $20,000 \mathrm{~kW}$ plant at Guizhou would support the extraction of newly discovered bauxite..$^{50}$ In early October 1943 , Savage responded with great interest and expressed his hope "that the negotiations between the Chinese representatives in Washington and State Department officials will terminate in a decision to send me to China." ${ }^{11}$ Savage informed Zhang of his trip to India and requested follow-up communication through diplomatic mail, which Zhang duly conveyed to his supervisors in New York.

Having opened up direct channels of communication, Chen and chief representative K. Y. Yin (Yin Zhongrong) began securing Savage's passage to China. 
They sought clarification from Savage if his trip to India was "sponsored by the American Government or the British government and through what Department of the United States Government were the arrangements effected." ${ }^{52}$ The NRC then obtained the necessary clearance to bring Savage to China by December 1943. Sun Yun-suan followed up by introducing Savage to his colleagues at the Electrical Power Bureau in Chongqing. ${ }^{53}$ Zhang asked his supervisors to expedite the process in his March 1944 memo to Chen Liangfu. He pointed out that the construction of Fontana Dam and Kentucky Dam was ending in a few months, which would free up the TVA to assist China. Zhang added that TVA had an unparalleled scope of expertise, ranging from hydraulics, power network management, and farmland and forest conservancy. ${ }^{54}$ Zhang Guangdou spent eight months working on various phases of the Fontana Dam project in North Carolina and saw firsthand how the TVA completed the project in about two years. ${ }^{55}$ Postwar China needed to build dams quickly, and only American federal agencies like the Bureau of Reclamation and TVA were able to deliver such accelerated development.

Savage set aside his work in India and departed for China in June 1944, as he found the Yangtze Gorges project to be more promising. His project along the Sutlej River at Bhakra in Punjab faced opposition from community leaders who feared that water from the reservoir would submerge a local temple. The locals also demanded that Savage scale down his project. ${ }^{56}$ The Yangtze Gorges project was the complete opposite of the case in Punjab. Hydropower development in China came under the NRC's centralized command. This afforded Savage the luxury of focusing on site selection and cost-benefit analysis, while his Chinese hosts dealt with the politics of population displacement. Savage arrived in China in June 1944, just as the Japanese captured strongholds in Hunan like Changsha and Hengyang during the Ichigo Offensive. Savage steered clear of military conflict by starting his surveys of the four Yangtze tributaries near the wartime capital Chongqing, namely Min River, Tuo River, Jialing River, and Wu River. Some four hundred miles downstream, Guomindang forces of the sixth war area were conducting a three-month campaign against Japanese forces in Yichangthe proposed site of the Yangtze Gorges Dam. Savage traveled to Xiling Gorge in western Hubei on September 20, 1944, when the fighting ended. Savage was within three miles of Japanese forces but took the risk to venture to the place that he described as "an engineer's dream site." 57

Accompanied by the commander of the Upper Yangtze Defense Force Wu Qiwei and Hydroelectric Bureau Chief Huang Yuxian, Savage traveled by boat along a two-and-a-half-mile stretch between Shipai and Pingshan, approximately fifteen miles upstream from Yichang (see figure 5.3). During the ten-day 


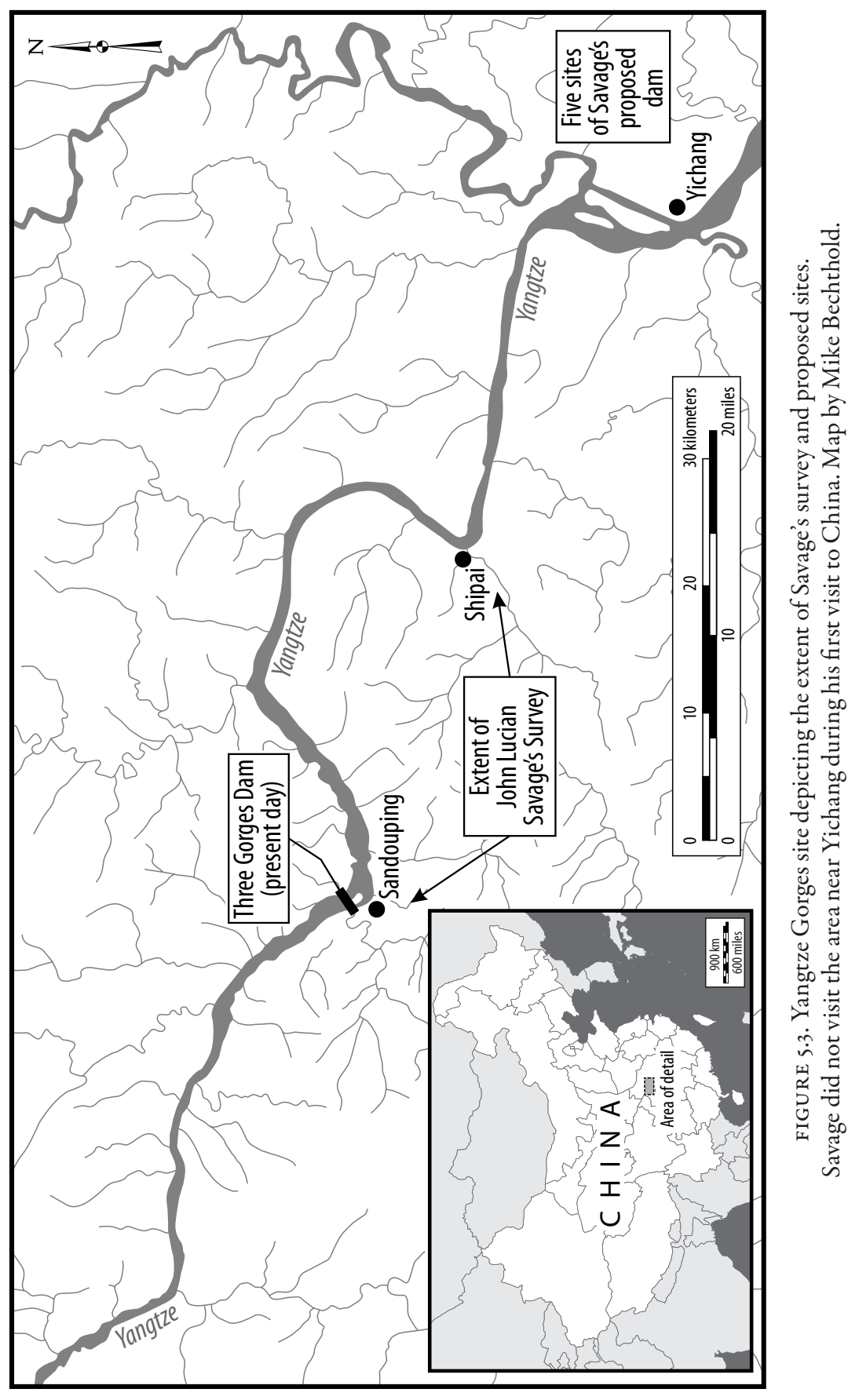


survey, Savage lacked the equipment to conduct a full geological profile, so he resorted to picking up rock samples while hiking along the banks. ${ }^{58}$ The local garrison showed Savage a topographical map captured from the Japanese, on which Savage based his calculations for drainage volume. Savage then returned to Changshou and spent the next forty days drafting his "Preliminary Report on the Yangtze Gorge Project." 59

Savage presented a wildly optimistic plan. He proposed the construction of a "concrete gravity dam" about 738 feet high that would raise the reservoir water by 525 feet. The power plant, with a firm power output of 7.8 million $\mathrm{kW}$ and secondary output of 2.7 million $\mathrm{kW}$, contains "twenty combined diversion and power tunnels on one side or both sides of the river." ${ }^{60}$ The multipurpose development project would also store enough water to irrigate ten million acres of farmland and be equipped with canal locks that allowed ships of ı,,००० tons to sail up the Yangtze to Chongqing. Savage estimated the entire project to cost 935 million US dollars and bring in 154 million US dollars of annual revenue. ${ }^{61}$ The TVA's Muscle Shoals Plant inspired the funding mechanism for its construction. George Reed Paschal, an engineer with the Foreign Economic Administration, proposed a "fertilizer for dam" financing scheme in August 1944. Paschal calculated that 400 cubic feet of water flowing through the narrow gorge at Yichang each second generated I0.5 million $\mathrm{kW}$. A fertilizer plant with an annual capacity of five million tons will use five million $\mathrm{kW}$, leaving the Chinese with the balance. At 4 percent interest, the Chinese would have paid off the loan in fifteen years, while the Americans acquired fertilizer at half the market price. ${ }^{62}$

Savage based his extrapolations on fragmentary and flawed data. Savage calculated the flood volume of the Yangtze with three data points - the flood water volume from 1896, 1905, and 1931. ${ }^{63}$ When he exhausted the NRC's sources and his direct observations, he turned to travel accounts by foreign observers, such as H. G. W. Woodhead's The Yangtsze and Its Problems dating back to 1931. ${ }^{64}$ Savage qualified his report stating that much work remains to be done. He noted that a review of preliminary economic studies, hydraulic model tests, stress and stability studies, contract designs, and final specifications had to be completed before construction. A large project like the Coulee Dam required at least 15,000 drawings. ${ }^{65}$ Savage also neglected to mention that a geological survey in the prospective sites had not yet been completed.

Savage stood on firmer ground with his detailed proposal for smaller hydropower projects on the upper Yangtze tributaries, which was submitted shortly after completing the Three Gorges report. He completed the drawings for three 
sites in Sichuan (Dadu River and Mabian River; Upper Minjiang and Guanxian; Longxi River) and one in Yunnan (Tanglang River) between September and November 1944. ${ }^{66}$ Savage stayed at a guesthouse near the Qingyuandong hydropower station in Changshou, which had been constructed by the NRC during the war and had supplied electricity to Chongqing since 1942. He thus had the benefit of making on-site observations and drawing on recent engineering reports completed by the NRC and their consultant Hugh L. Cooper and Company. His itemized cost estimates for these smaller project sites were much more precise. The Dadu River-Mabian River (I.2 million kW) and Upper Minjiang (820,000 kW) projects, projected to cost 336.0 million US dollars and I99.7 million US dollars respectively, were not only described as "feasible in respect to their construction" but also "SUPER-PROJECTS of great potential value to China." The Longxi River and Tanglang River projects, which would have been expansions of existing hydropower stations, were 5 to ro percent the size of the first two projects. The Longxi River project called for the construction of three hydropower stations with a combined total output of $49,500 \mathrm{~kW}$ around the existing 3,000 kW Lower Qingyuandong hydropower station at II.2 million US dollars. The Tanglang River project, which diverted water from Kunming Lake, Anning, and Fuming, required a 16.3 million US dollar budget and added $80,000 \mathrm{~kW}$ of generating capacity. ${ }^{67}$

Upon completing the preliminary report, Savage sought final approval for the conclusion of a cooperative agreement from the Department of the Interior and the State Department. He cabled the commissioner of the Bureau of Reclamation on September 26, 1944, to inform him of Chinese interest in the Yangtze Gorges project within days of submitting his report. The commissioner supported Savage's actions and notified the secretary of the interior on October I8, 1944, that the Bureau intended to grant assistance. Ten days later, the commissioner cautioned Savage that "any final plans must be prepared by the State Department," and that the Bureau prioritized domestic work over the demands of the Chinese government and undertook no financial responsibilities for the project. ${ }^{68}$ Negotiations of the cooperative agreement stalled, as Sneddon duly noted, because the desire to "put its prodigious technical capabilities to work on a once-in-a-lifetime project" on the part of Savage and the Bureau of Reclamation came into conflict with the State Department's cautious approach. ${ }^{69}$ During a meeting on March 10, 1945, First Assistant Secretary of the Interior Benjamin Strauss objected to a clause of confidentiality as the Bureau had a long-standing policy of making engineering techniques and discoveries open to the world. ${ }^{70}$ In May 1945, the State Department withheld its approval for the agreement raising 
concerns about the project's feasibility stating that, "such as vast quantity of power as the project would develop appears to be out of line with the capacity of China's industry to utilize that power in the foreseeable future." Strauss replied by invoking the TVA's experience that the availability of cheap hydropower and irrigation water led to accelerated development of agriculture and industry and that assisting China was in line with the United States's national interest. ${ }^{71}$ Savage's retirement from the Bureau on May 9, 1945, released him from bureaucratic encumbrance. ${ }^{72}$ But without a formal Sino-American cooperation agreement, Savage was unable to achieve anything.

Savage delegated his China portfolio to John S. Cotton, formerly a senior engineer of the Federal Power Commission's San Francisco regional office. On December 9, 1944, the NRC appointed Cotton as the "Chief Investigating Engineer to work on river-basin and electric investigations." ${ }^{\text {"3 }}$ Cotton outlined his plans for a comprehensive survey of the Yangtze River basin from his home in San Francisco before meeting the globe-trotting Savage in Denver on March I4, 1945. ${ }^{74} \mathrm{He}$ departed for China with Zhang Guangdou in April 1945, not before getting immunized for cholera, typhus, typhoid, small pox, and bubonic plague, while securing thirty-five pounds of excess baggage for his technical notes. ${ }^{75}$ Cotton did not even bid farewell to his wife before his departure. He forwarded her a copy of his reimbursement and insurance policy through the NRC's New York office. ${ }^{76}$

In the early months as chief engineer of China's National Hydroelectric Bureau, Cotton took a conservative approach by prioritizing the construction of small hydropower stations around Chongqing over the hydrological surveys for the Yangtze Gorges. Cotton started by presenting his tentative outline for his report on the economies and planning of the Yangtze Gorges project in May $1945 .{ }^{77} \mathrm{He}$ released a report in August 1945 proposing the construction of low dams near Yichang, "with the view of early and rapid construction of about I,500,000 firm kW to meet the great and urgent demand for industrial power in the central region of China." The low dams were half the height of that in Savage's proposal and created a smaller catchment area; the powerhouse was equipped with twenty $75,000 \mathrm{~kW}$ generator units, rather than ninety-six generators. With no reliable data, Cotton drew on Savage's initial calculations and estimated the project to cost between 197 million and 313 million US dollars. ${ }^{78}$

Cotton also obtained a more precise understanding of the topography near Yichang. The Hydroelectric Engineering Bureau lacked the equipment to conduct detailed surveys. It acquired office supplies such as compasses, slide rules, photo-stat machines, and calculators from the American military forces about to 
withdraw from Chongqing. ${ }^{79}$ The NRC attempted an aerial survey on its own. It borrowed an F-5 reconnaissance plane in August 1945 from the Aviation Affairs Commission to take aerial photographs that would be used to prepare a I:25,000 map. ${ }^{80}$ Cotton reached out to the TVA for help in September 1945, only to be told that "under the authority of the TVA act we cannot undertake work on a reimbursable basis directly from a foreign government." ${ }^{81}$ The TVA, however, offered to prepare a map from the photos taken. Avenues for assistance such as Lend-Lease were being closed off as the war ended.

With the lack of accurate topographical data and guidance from their American advisers, the National Hydroelectric Engineering Bureau shelved the Yangtze Gorges project until the cooperative agreement was concluded on October I, 1945. The commissioner of the Bureau of Reclamation assigned the Yangtze Gorges project to the Branch of Design and Construction, but even then formal studies did not begin until June 3, 1946. ${ }^{82}$ Before March 1946, Savage was tied up with projects in India and Palestine. ${ }^{83}$ With the Yangtze project in limbo, Cotton directed his energy toward the smallest hydropower project proposed by Savage's November 1944 report - the Longxi River hydropower project. In fact, Cotton only visited the Yangtze Gorges project site for the first time in February 1946, just as Savage was planning to return to China. ${ }^{84}$

The Longxi River hydropower project promised a quick reprieve from Chongqing's power shortage. According to Cotton's planning report published on September 28, 1945, Chongqing had only four power stations with a combined output of $\mathrm{I} 2,000 \mathrm{~kW}$, while its industries supplied their own electricity by installing generators with a total capacity of $17,900 \mathrm{~kW}$. Cotton estimated that Chongqing required an output of $135,000 \mathrm{~kW}$. Based on this projection, there would be 200,000 new residential customers in Chongqing with an average individual annual consumption of $300 \mathrm{kWh}$. Damming the Longxi River, a Yangtze River tributary ninety kilometers downstream from Chongqing, would create a 2,900-square-kilometer reservoir with enough water to power four hydropower plants totaling 64,000 kW, which would meet half the projected demand. An additional steam power plant added $16,000 \mathrm{~kW}$ of firm power. Cotton adopted a cautious approach by dividing the development into two stages and choosing the cheapest construction method. The initial development required the construction of the Lion Rapids Reservoir and Dam and one $15,000 \mathrm{~kW}$ power plant at Lion Rapids and one $10,000 \mathrm{~kW}$ power plant at Upper Qingyuandong. In the second stage, a 6,000 kW plant would be built in Huilongzhai and 30,000 kWs of additional capacity would be installed at the existing Lower Qingyuandong plant. His cost estimate of 7.494 million US dollars was lower than Savage's 
earlier proposal. The submerging of 43,500 $\mathrm{mu}$ of arable land would displace 7,229 inhabitants, but Cotton surmised that increased employment from local industries outweighed the loss of farmland. ${ }^{85}$

Cotton did not appear to know about the resentment arising from hydropower development near Chongqing. The damming of the Longxi River in 1942 had already increased local flood risk. Tensions over the hydropower plant boiled over after a flood on September 30, 1945, just two days after Cotton transmitted his Longxi River planning report. The waters of Peach Blossom Creek surged after a severe thunderstorm resulting in a flood near Ranshi Bridge. The villagers reported that flood waters washed away a flour mill and damaged the sweet potato harvest. The villagers blamed a defective sluice gate that did not open fully to release the flood waters. The chief of Duzhou Village, Zhou Zhilu, demanded compensation from the Longxi River Engineering Office. ${ }^{86}$ Huang Yuxian, then director of the Longxi River project and later promoted to the head of the National Hydroelectric Engineering Bureau, insisted that the sluice gate had nothing to do with the flooding. He pointed out that local residents had been receiving a monthly allowance after a 1944 flood to maintain a flood-prevention team and neglected their duties of opening the sluice gate during the September 1945 flood. Huang then asserted that the damages at Duzhou Village were no more serious than those in neighboring villages, then questioned why the residents did not move their food and personal property to higher ground to avoid a few inches of floodwater.$^{87} \mathrm{After}$ months of investigations, the NRC approved compensation of $700,000 \mathrm{CNC}$ dollars, amounting to about io percent of that demanded by the villagers in May 1946, while acceding to an increased monthly flood-management allowance. ${ }^{88}$

Blissfully unaware of local opposition, Cotton went ahead with drafting invitations for bids shortly after filing the report. The National Hydroelectric Bureau imposed strict deadlines on prospective contractors to safeguard against default. For example, the contractor had to deliver two $9,000 \mathrm{~kW}$ turbines along with the governor, butterfly valve for the Lion Rapids plant to Shanghai, with the first complete unit arriving within 250 days and a second one within 350 days. The delivery of one $10,000 \mathrm{~kW}$ power plant for Upper Qingyuandong had to be completed within 150 days. Once awarded the contract, the contractor had to post a performance bond of "not less than 50 percent of the estimated aggregate payments to be made under the contract." They were also subject to fines of 20 US dollars per day for each item delivered late. ${ }^{89}$ As no suppliers in China were capable of fulfilling these orders, the NRC's New York office conducted the invitation to tender in the United States. The NRC only had a 
budget of 4 million US dollars, which was lower than the prevailing price of the equipment. It even had to remove concrete from the purchase list to stay within budget - a move that ultimately hampered dam construction at Lion Rapids. ${ }^{90}$

Savage's return to China in March 1946 forced Cotton to redirect his focus to the Yangtze Gorges survey and set aside the work on the Longxi River project. After arriving in Chongqing, Savage headed to Changshou to convene with Cotton and his colleagues at the Hydroelectric Engineering Bureau. ${ }^{91}$ Savage assembled a stellar engineering team. W. C. Beatty, retired chief mechanical engineer of the Bureau of Reclamation, supervised and coordinated all aspects of the Yangtze Gorges study. Fred O. Jones, a thirty-four-year-old geologist who had worked on the Columbia River Basin project, directed the testing of the limestone bedrock near Yichang. Jones recognized the enormity of the mission, describing the gorge as one "deeper and steeper than our Columbia River canyon." Morrison-Knudsen sent a high-ranking drilling superintendent to complete the geological drilling after company representatives met with Savage in Shanghai. Savage also set up contract negotiations for an aerial topographical survey of the Yangtze Basin between the vice president of Fairchild Aerial Survey and the Chinese government. ${ }^{92}$ Before his departure, Savage left general instructions for further studies of five possible project sites and more detailed topographical studies. He had little to say about the Longxi River project after a routine inspection, besides stating that he found the design and plans to carry out construction by manual labor to be satisfactory. ${ }^{93}$

News of Savage's efforts to jumpstart the next phase of the Yangtze Gorges project generated great excitement. The project came to symbolize hopes for a prosperous future under a strong central government. A Guomindang party cadre Sun Danchen went as far as to compare Savage to Li Bing, the Qin statesman credited with building the Dujiangyan-an irrigation system that transformed Sichuan into a productive tax base, which ultimately gave the Qin an advantage over their Warring States rivals. Besides relieving flooding in western Sichuan and irrigating 5.2 million mu of land in eleven counties, the Dujiangyan opened a transportation channel for timber to be shipped from southern Sichuan. ${ }^{94}$ News bulletins referred to the Hydroelectric Bureau as the Yangtze Valley Administration (YVA). The author went further to suggest that the YVA had greater potential than the TVA by virtue of its wider geographical coverage and larger projects. ${ }^{95}$ If, in the words of David Ekbladh, "the TVA's mission was to turn the ornery Tennessee River from an unpredictable force into a docile servant for regional development," then the YVA aimed to transform the Yangtze into the driving force for national development. ${ }^{96}$ 
Further feasibility studies conducted after June 3, 1946, began exposing problems with Savage's preliminary proposal. The Bureau of Reclamation's chief engineer delayed the assignment of engineers to the Yangtze project until May 30, 1946. ${ }^{97}$ Within two weeks, Chinese engineer C. Y. Pan alerted Savage to inaccuracies in the topographical maps that served as the basis for his 1944 report. Savage's team had determined the contour intervals on the map to be thirty meters by looking at the numbers marked out on a series of contours. An accurate translation revealed that these were not elevation figures in the first place. Furthermore, the map was made with aerial photographs taken in July 1940 when the water level at Yichang was fifty meters higher than normal. These threw off all the initial estimates. With no further information, the engineers assumed that the contour intervals were ten meters, as per mapping conventions and calculated that a dam at proposed number 4 site needed to be 2,400 feet longer than the original..$^{98}$ Later reports revealed elevation figures to be "inaccurate as much as 600 to 1,000 feet." The survey team had to wait until January 28, 1947, before reliable data from aerial surveys became available. ${ }^{99}$

The scale of the Yangtze Gorges project expanded uncontrollably with the completion of further electrical equipment studies. Savage's 1944 report proposed the installation of sixty power units of $175,000 \mathrm{~kW}$ for a total capacity of 10.5 million kW. In his revised plan in March 1945, Savage conceived something even bigger. He planned on building twenty diversion tunnels each thirty feet in diameter and adding another four after the completion of the dam. Each of these twenty-four tunnels would be installed with four II0,000 kW power units, bringing the total installed capacity to 10.56 million $\mathrm{kW}$. When Beatty took over from Savage, he factored in the flow rate of the river and increased the power rating and number of generators required. Beatty's August 1946 plan estimated configurations of 96,114 , or 126 units of $175,000 \mathrm{~kW}$ each. ${ }^{100}$

The technology that existed at that time made it difficult if not impossible to generate such a vast amount of electricity and transmit it over a long distance. A further study about the suitability of $200,000 \mathrm{~kW}$ turbines proposed for the Yangtze by Champe Lu in January 1947 noted that "the maximum head of the Yangtze turbine of 535 feet as compared to 355 feet on the Grand Coulee Unit introduces greater stress in such parts as scroll cases, speed ring, wicket gates and runners." Lu added that the parts were made of cast steel and should have ample strength to deal with the conditions on the Yangtze. ${ }^{101}$ Plans to construct 330 $\mathrm{kV}$ transmission line from the Yangtze Gorges Dam would, however, prove to be less feasible. General Cable Corporation pointed out that the highest operating voltage available was $230 \mathrm{kV}$. To reach the desired voltage, the pressure rating 
for the oil-filled transmission cables had to be doubled from $250 \mathrm{psi}$ (pounds per square inch) to at least $500 \mathrm{psi}$, which was outside the operating range of existing oil pressure control equipment. ${ }^{102}$

Geological studies also called into question the suitability of four out of five sites. Between October and December 1946, Hou Defeng and four other geologists from the Central Geological Institute conducted a preliminary survey in Yichang. The geological team from Morrison Knudsen did not arrive until November 1946, as a dock strike in the United States delayed the shipping of drills. On their own, Chinese geologists constructed a complete geological column of the Yichang area, covering an area of one square kilometer. Fred Jones did a follow-up study in March and June 1947. The results were disappointing. The bedrock for sites number 4 and 5 was tertiary Shimen conglomerate, susceptible to leaking. The bedrock at site I A was crushed limestone, which was not an ideal foundation for dam construction. The geological team found site number I to be even less suitable due to a crumbly layer of shale. Only the bedrock at sites number 2 and 3 was firm enough. Even then, the large numbers of caves in site 3 rendered it unsuitable, as the dam would have to be extended by about 2,000 meters. ${ }^{103}$

Scrutiny during the final months of the study raised concerns on the durability and benefits of the proposed megadam. The severity of sedimentation only came to light two months before the termination of the Yangtze Gorges survey. E. W. Lane, with the assistance of Chinese engineer W. Y. Yu, calculated the sediment volume by using fragmentary historic data and gathering samples with sediment traps from nine gaging stations along the Yangtze and two tributaries (Jialing and Wu Rivers). The data did not yield an accurate estimate but raised enough cause for concern. Lane noted that the wide variation of sediment discharge from the Jialing River placed the annual discharge volume between I50,000 to 600,000 acre-feet. He calculated the total suspended load to be between 350,000 acre-feet to 775,000 acre-feet, yielding an approximate lifespan for the dam of between 127 and 207 years. The report also suggested that deposition near Chongqing during the dam construction would affect the navigability of the Yangtze by reducing the river's depth and limiting the draft of the vessels sailing up to Chongqing. ${ }^{104}$

Cost estimates skyrocketed as these detailed studies emerged. The cost of river diversion had to be revised upward from Savage's preliminary estimate of I54 million US dollars to 392 million US dollars following detailed topographical surveys that offered a full calculation of the drainage area. ${ }^{105}$ As planners increased the generating capacity to reduce average cost of electricity, they not only called for the installation of larger and more expensive turbines but also 
increased the number of diversion tunnels that needed to be built. The financial study released in May 1947 placed the cost of the power generating facilities alone between 1.683 and 1.8165 billion US dollars, almost double that of Savage's original estimate. The lower-end estimate was achieved by deferring part of the structural work after the completion of the upstream construction. ${ }^{106}$ The average construction cost of 67.76 US dollars per kilowatt power generated was one third that of the Dajia River Integrative Development undertaken by the Japanese in Taiwan during World War II. ${ }^{107}$ Three days after the release of the financial study, the Nationalist government implemented the emergency economic program and suspended the Yangtze Gorges study. Two months earlier, the Nationalist government had withdrawn forces from Hubei and curtailed funding to the project. Despite pleas from Cotton for the "existing contract [to] be kept alive or small scale by use of existing staff," the Executive Yuan terminated the services of the geological surveyors Morrison Kundsen Company. ${ }^{108}$ At Yun Zhen's request, the Bureau of Reclamation issued a status report of all work completed by August 15, 1947, and preserved the studies and working files. Beatty expressed regret about the demise of the study and noted that it was "difficult to leave the work in proper shape for completion in the future."109

Despite these troubles, Savage and Cotton remained hopeful for the revival of the Yangtze Gorges Dam project. In a 1948 interview, Savage believed that the project was "still alive," as he "sees it as a great, strong heart, pumping the lifeblood of electrical power, new industry and renewed agriculture into the veins of a revitalized China." ${ }^{110}$ Cotton moderated his expectations. Earlier projections that the Yangtze Gorges Dam could be completed in eight to ten years proved to be unrealistic. In a speech to his Chinese colleagues, Cotton reminded them that the Three Gorges Dam was five times the size of Grand Coulee Dam, which was then the largest hydropower station. It took thirty-four years to complete the Grand Coulee. ${ }^{111}$ All the work was not in vain, however. On April I2, 1948, the Chinese representatives in Denver sent back two big boxes of materials to Nanjing, which included 193 sheets of topographical maps of South China from the US Army, thirty-eight sheets of navigational maps of the Yangtze River from Yichang to Chongqing, and several copies of climatological data. ${ }^{12}$ Their work laid the foundation for future hydropower development in the Yangtze.

Faced with this setback, Cotton redirected his focus to the Longxi River project in Sichuan. Excavation and damming at Longxi River had barely gotten any attention thus far, as the Hydroelectric Bureau diverted its attention to the Yangtze Gorges survey in March 1946. Half of the Hydroelectric Bureau's 305 staff members were tied up with the Yangtze Gorges, while the remaining staff was sent to 
Northwest China, western Sichuan, and the Qiantang River to conduct surveys. ${ }^{113}$ As early as July 1946, Cotton alerted Huang Yuxian of the material shortage at the Longxi River project, stating that, "The only good construction equipment at Upper Tsing Yuan Tung [Qingyuandong] is one compressor, one wagon drill and four jackhammers." Only one out of four trucks obtained from the NRC was working. ${ }^{114}$ By September 1946, only the design work has been completed; funds for the purchase of generators never came through. With no bids received from the earlier call for tender, Cotton fell back on an earlier batch of components that had been purchased in 194I through the Lend-Lease Act. Hundreds of parts for four I,000 hp turbines, designated for the Lower Qingyuandong Power Plant, finally arrived in Shanghai in November 1946 after sitting in storage in India for years. They remained in hundreds of crates scattered across four warehouses in Shanghai, as the Longxi River project remained at a standstill. ${ }^{115}$

Problems with the building materials caused the construction of the dam to grind to a halt. In September 1947, Cotton issued a concrete testing report, which noted that the sandstone from a nearby quarry was so brittle that it could "be scratched with a pocket-knife" and "much more porous than ordinary sedimentary rock." Bleeding, where water comes out to the surface, occurred in all different grading of sand. The durability and strength of concrete mixes were also questionable. Furthermore, due to the poor conditions of the laboratory, engineers were unable to complete permeability testing. ${ }^{116}$ Zhang Guangdou had projected the Upper Qingyuandong hydropower station to enter service in the middle of 1948. This did not happen. Labor shortage further slowed down the progress. Engineers at the Upper Qingyuandong reported that workers continued working on the project in August 1948 even though they did not receive their wages. Construction activity stopped one month later when workers returned to their fields to tend to their harvests. ${ }^{117}$ The National Hydroelectric Engineering Bureau, which aspired to be China's TVA, lacked the capability to complete the smallest hydropower plant in its project pipeline.

SetbaCKS IN THE Yangtze Gorges and Longxi River projects did not deter visionaries like Savage and Cotton. Just as further studies revealed major flaws in Savage's ambitious 1944 proposal for the Yangtze Gorges Dam at Yichang, Cotton drafted similar plans for integrative developments elsewhere in China. He conveyed the wild optimism in Savage's visions for his plans in Guangdong, Fujian, Yunnan, and Hunan. In his April 1948 report, Cotton envisioned the construction of a large synthetic nitrogen fertilizer plant capable of producing 240 tons of ammonium sulphate per hour, which would consume 20 percent of 
the newly available electricity from the Weng River hydropower project. ${ }^{118}$ The attempt to replicate the Muscle Shoals fertilizer plant simply shifted from the upper Yangtze to the Pearl River Delta.

Contrary to existing studies that painted Savage as a visionary who was ahead of his time, this chapter brings into focus his failure to consider the cost of accelerated development promised by integrative river basin projects. Efforts to replicate the TVA's achievements in China also exposed the limitations of this developmental model. The engineers had worked on the assumption that the war had wiped the slate clean and paved the way for China's electrical industries to cast aside troubled beginnings and start afresh. Development plans for the Yangtze Gorges promised the deliverance of exponential economic growth but glossed over negative effects like farmland loss and population displacement. Even as they embarked on small-scale hydropower projects, the National Hydroelectric Bureau of the Guomindang regime struggled to deal with resistance from the local population and confronted shortages in funds and construction equipment.

The colossal scale of Savage's proposed dam required a massive transformation of the natural environment that not only impacted the local ecosystems but would also result in a gestalt shift in the geosphere and biosphere of the Earth system. While the term Anthropocene had not come into existence during Savage's time, the dam builders understood their projects as attempts to overcome geological and hydrographic constraints shaped by deep time. Projections of the dam's lifespan measured in tens of decades suggest the acceleration of changes in topography and hydrography that would have otherwise taken millennia. Interventions meant to extend the lifespan of the dam required humans to act as geological agents. Using the newly harnessed electricity to power the Haber-Bosch process would also speed up the nitrogen cycle and lay the groundwork for explosive population growth. The movement of vast amounts of electricity over long distances with high voltage networks called for the redesign of power transmission systems. Savage's earlier developmental vision evoked a future where mankind would create the stratigraphic and functional change for perpetual economic growth.

Savage's plan should not be dismissed as a footnote in hydropower development on both sides of the Taiwan Strait. Sun Yun-suan, who moved to Taiwan and rose through the ranks in the Taiwan Power Company, oversaw the development of major hydropower projects in Taiwan with American aid. ${ }^{119}$ In mainland China, the proliferation of small hydropower stations in the $1950 \mathrm{~s}$ followed in the wake of the initial setbacks in grandiose plans for integrative 
river basin developments. Zhang Guangdou, who had worked closely with Savage and Cotton, picked up where the two visionaries left off and advocated for its construction in the 1970 and 1980 os. Construction for the Three Gorges Dam began in 1994. It entered service in 2003. The belief that man could conquer nature that emerged in the dreamscapes of Savage's Yangtze Gorges Dam is still alive and well. During the massive summer floods in 2020, Chinese state media acknowledged that the Three Gorges Dam was slightly deformed as it held back the stormwater but readily refuted claims that the megadam was structurally unstable as unscientific.

The National Hydroelectric Bureau had tried to turn the tide of China's declining fortunes by leveraging its connections with the TVA. It ultimately spread itself too thin by juggling small hydropower projects and the Yangtze Gorges survey. Cotton had a nagging concern throughout his tenure as chief engineer. The Little Fengman Dam along the Sungari River in Northeast China remained in a state of disrepair. The Communists soon took advantage of the destabilization of local society resulting from the power shortage and established a foothold in the Northeast. They would soon learn how to use electricity as weapon in urban warfare and turn the tide of the civil war in their favor. 